DOI: $h$ ttps://doi.org/10.31933/dijemss.v2i4 Received: $29^{\text {th }}$ March 2021, Revised: $15^{\text {th }}$ April 2021, Publish: $25^{\text {th }}$ April 2021

$\begin{array}{llr} & \text { DIJEMSS } \\ & \text { DINASTI INTERNATIONAL JOURNAL } \\ & \text { OF EDUCATION MANAGEMENT AND } & \text { https://dinastipub.org/DIJEMSS } \\ \text { editor@dinastipub.org } & 08117401455 @ \\ \text { PUNASTISHER } & \text { SOCIAL SCIENCE }\end{array}$

\title{
THE POSITIVE EFFECT OF TOTAL QUALITY MANAGEMENT (TQM) ON THE ACHIEVEMENT OF CLINICAL QUALITY INDICATORS IN INPATIENT UNITS OF TANGERANG DISTRICT HOSPITAL ASSOCIATED BY NURSE PERFORMANCE
}

\author{
Heri Danuri $^{1}$ M. Natsir Nugroho ${ }^{2}$ Yanuar Ramadhan $^{3}$ \\ ${ }^{1}$ Esa Unggul University, herdan.danuri@ gmail.com \\ ${ }^{2}$ MARS Lecturer, Esa Unggul University Jakarta \\ ${ }^{3}$ MARS Lecturer, Esa Unggul University Jakarta, yanuar.ramadhan@esaunggul.ac.id
}

Corresponding author: ${ }^{3}$ yanuar.ramadhan@esaunggul.ac.id

\begin{abstract}
An indicator of clinical quality is a valid and reliable quantitative process related to one or more performance dimensions. The achievement of clinical quality indicators is strongly influenced by the performance performed by a nurse and is supported by a quality program known as Total Quality Management (TQM). The poor achievement of clinical quality indicators in the inpatient unit at the Tangerang District Hospital is a strong reason to find out what factors can influence it and find a solution. This study aims to analyze the effect of TQM on the achievement of clinical quality indicators in the inpatient unit of Tangerang District Hospital mediated by the performance of nurses on 217 implementing nurses through a causal descriptive quantitative approach and using SEM analysis. Data collection techniques use primary and secondary data. The results obtained: (1) TQM has a positive effect on the achievement of clinical quality indicators mediated by the performance of the nurses; (2) TQM has a positive effect on the achievement of clinical quality indicators; (3) the performance of nurses has a positive effect on the achievement of clinical quality indicators; (4) TQM has a positive effect on nurse performance.
\end{abstract}

Keywords: TQM, Nurse Performance, Clinical Quality Indicators

\section{INTRODUCTION}

It has been the last one year that the people of Indonesia and also the world have been shocked by the outbreak of a new type of corona virus (Novel Corona Virus or nCoV), or now officially referred to as COVID-19 which stands for "coronavirus disease". It is hoped that the COVID-19 outbreak can also be used as a momentum to study and improve the 
implementation of the concept of good clinical governance as one of the concepts of efforts to improve the quality of clinical services.

A hospital with good quality will very much depend on the existing resources in the hospital such as the quality of services for doctors, nurses, staff, and employees as well as the available facilities and infrastructure. The capacity of health services, especially in hospitals, demands a transformation towards management change called 'Total Quality management' (TQM) which means the application of quantitative methods and human knowledge to: 1. Improve materials and services that are input to the organization, 2. Improve all important processes in the organization, 3. Improve efforts to meet the needs of users of products and services at present and in the future (Syarhan. H, 2017)

Efforts to improve the quality and performance of clinical services are generally initiated by nurses through various forms of activities. In health services, the performance of nurses itself is still a problem that needs attention to maintain the quality of services provided.

Several research results show data about the poor performance of nurses in various countries. Research by Mukhtar et al., (2019) the performance of nurses at Sudanese Hospital was still low, only 32\%. Research at Tertiary Hospital, Emergency Department in Gaeteng Provine, South Africa found that the performance of nurses in conducting assessments was still low, only 68.3\% (Goldstein et al., 2017). Research at the Tengku Ampuan Afzan (HTAA) Hospital, Kuantan, Pahang, Malaysia found that the performance of nurses in assessing patients was still low, only 76.5\% (Aung et al., 2017). From some of the research results above, it is stated that the performance of nurses is in the poor category and becomes a problem in providing health services to patients, including in Indonesia.

Tangerang District General Hospital is a referral hospital for Banten Province which has been established since 1928 with a service capacity of 496 beds and has specialist and subspecialty services in 27 fields with excellence in integrated cardiac services, thalassemia, maternal and neonatal.

The data obtained from the Quality Improvement and Patient Safety (PMKP) section shows that the clinical quality indicators of inpatient units obtained in 2019 at the Tangerang District Hospital, from the 6 existing indicators, it was found that 3 indicators had low achievements so they needed follow-up. The three indicators include: 1 . The incidence of transfusion reactions of $0.43 \%$ of the $0.01 \%$ target, 2 . Phlebitis $4.4 \%$ of the $5 \%$ target, although it looks good in its achievements, but when compared to previous achievements this figure has increased considerably. so it needs attention. The last 3. Non-adherence of drug administration 5 is true with the achievement of $10.7 \%$ of the target of $0 \%$. (PMKP General Hospital Tangerang Regency, 2019).

The purpose of this study was to determine how the effect of TQM applied in the Tangerang District Hospital and the performance of nurses on the achievement of clinical quality indicators in the inpatient unit of the Tangerang District Hospital.

In general, the notion of indicators is a control variable that can be used to measure changes that occur in an event or activity. Clinical quality indicators are measures of clinical management or service outcomes and are expressed in numbers (Collopy, 2000).

Clinical quality indicators are valid and reliable quantitative process or outcome measures related to one or more performance dimensions such as effectiveness and appropriateness and statistical values that provide an indication of the condition or direction of organizational performance over time for a particular outcome (Grimby, 1993).

Total Quality Management (TQM) also called Integrated Quality Management or Integrated Quality Management is a management approach to an organization, centered on quality, based on the participation of all its members and aims for long-term success through customer satisfaction, and benefits to all members of the organization and society. 
W. Edwards Deming (1986) in his book entitled Out of the Crisis says that the implementation of the concept of quality in an organization requires a change in the philosophy that surrounds management.

Goetsch and Davis (2010) revealed that there are ten characteristics of Integrated Quality Management as follows :

1. Focus on the customer

2. Obsession with quality

3. Scientific approach

4. Long term commitment

5. Teamwork

6. Continuous system improvement

7. Education and training

8. Freedom under control

9. Unity of purpose

10. There is employee involvement and empowerment

Performance is the result of work that has a strong relationship with the organization's strategic goals, customer satisfaction and makes an economic contribution (Armstrong \& Baron, 2007).

The performance of nurses is summarized in the nursing care process. The nursing care process in Potter and Perry (2005) consists of five parts, including:

1. Nursing assessment

2. Nursing diagnoses

3. Nursing planning

4. Implementation of nursing

5. Nursing evaluation

\section{RESEARCH METHODOLOGY}

The research was conducted at the Tangerang District Hospital, Banten. Research time for 3 (three) monthsbetween August to October 2020.The research method uses associative quantitative methods with hypothesis testing to see the influence between variables. Population are all nurses in inpatient units as many as 217 people. Accidental sampling technique is used to collect samples from the existing population. The data used in this study are primary data and secondary data.

The research variables consisted of integrated Quality Management / TQM (X1), nurse performance (X2) and the achievement of clinical quality indicators (Y). The hypothetical framework in this study is stated in the relationship model between constructs as follows:

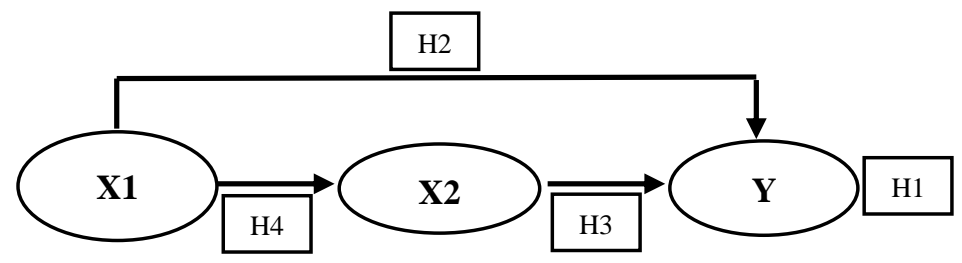

Figure 1. Hypothesis framework

In accordance with the objectives underlying this study, 4 hypotheses were developed as problem solving in this study, including: 


\section{Hypothesis 1}

H0: there is no positive effect of TQM on the achievement of clinical quality indicators in the inpatient unit of the Tangerang District Hospital, mediated by the performance of nurses.

H1: there is a positive effect of TQM on the achievement of clinical quality indicators in the inpatient unit of the Tangerang District Hospital, mediated by the performance of nurses.

\section{Hypothesis 2}

H0: there is no positive effect of TQM on the achievement of clinical quality indicators in the inpatient unit of the Tangerang District Hospital.

H1: there is a positive effect of TQM on the achievement of clinical quality indicators in the inpatient unit at the Tangerang District Hospital.

\section{Hypothesis 3}

H0: There is no positive effect of nurse performance on the achievement of clinical quality indicators in the inpatient unit of the Tangerang District Hospital.

H1: There is a positive influence on the performance of nurses on the achievement of clinical quality indicators in the inpatient unit at the Tangerang District Hospital.

\section{Hypothesis 4}

H0: There is no positive effect of TQM on the performance of nurses in the inpatient unit at the Tangerang District Hospital.

H1: There is a positive effect of TQM on the performance of nurses in the inpatient unit at the Tangerang District Hospital.

\section{Validity and Reliability Test}

The validity test was carried out by comparing the Cronbach's Alpha value on each dimension with the Cronbach's Alpha value if Item deleted on each indicator (Singgih Santoso, 2015). Based on the results of the analysis, it is known that 51 indicator items are declared valid and 11 items are invalid and are declared invalid for further processing.

Based on the reliability analysis obtained that overall all variables are said to be reliable because they have met the required requirements, namely having a minimum construct reliability value between 0.6 to 0.9 .

The univariate data normality test was carried out descriptively by looking at the normal QQ plot. Theoretically, a data set is said to have a normal distribution if the data is scattered around the line. From the output, we obtain a QQ plot for all variables scattered around the line and none far away of the line so that it can be said that the data is normally distributed.

\section{Evaluation of Goodness of Fit Criteria}

Based on the full model analysis, it can be shown that the model meets the marginal fit criteria. This can be explained by the value of the calculation results that meet the eligibility criteria for the model, in detail presented in Table 1.

Table 1. Evaluation of Goodness of Fit Criteria

\begin{tabular}{|c|l|c|c|c|}
\hline No & \multicolumn{1}{|c|}{ Criteria } & Criteria & Result & Information \\
\hline 1 & $\mathrm{X}^{2}$ Chi-square & $\begin{array}{l}\text { It is expected that the value is } \\
\text { small with } \mathrm{DF}=331, \text { the } \\
\text { table value }=374.42(0.05)\end{array}$ & 3021,27 & Poor Fit \\
\hline 2 & P-level & $\geq 0,05$ & 0,00 & Marginal Fit \\
\hline 3 & RMSEA & $\leq 0,08$ & 0,19 & Marginal Fit \\
\hline 4 & GFI & $\geq 0,90$ & 0,50 & Marginal Fit \\
\hline 5 & CFI & $\geq 0,90$ & 0,32 & Marginal Fit \\
\hline 6 & CMIN/DF & $\leq 2,00$ & 9,12 & Poor Fit \\
\hline 7 & TLI & $\geq 0,90$ & 0,28 & Marginal Fit \\
\hline
\end{tabular}


Based on Table 1, the results of the calculation of the chi-square test on the full model obtained a value of 3021.27 which means that it does not meet the required requirements, but this value can be accepted marginally and can perform further analysis by looking at the RMSEA, GFI, TLI and CFI values that have met marginal fit criteria, then further analysis can be carried out. Based on these results, it can be explained that the model in this study as a whole meets the criteria as a marginal fit model.

The result of this marginal fit can be due to the primary data of the respondents' answers which may be influenced by the work environment in the Tangerang District Hospital, both internal and external. The data for all $\mathrm{X}$ variables are only in the medium category and not high.

Testing of the research model was carried out using Structural Equation Modeling (SEM) with the Confirmatory Factor Analysis (CFA) method

\section{Data Analysis Phase}

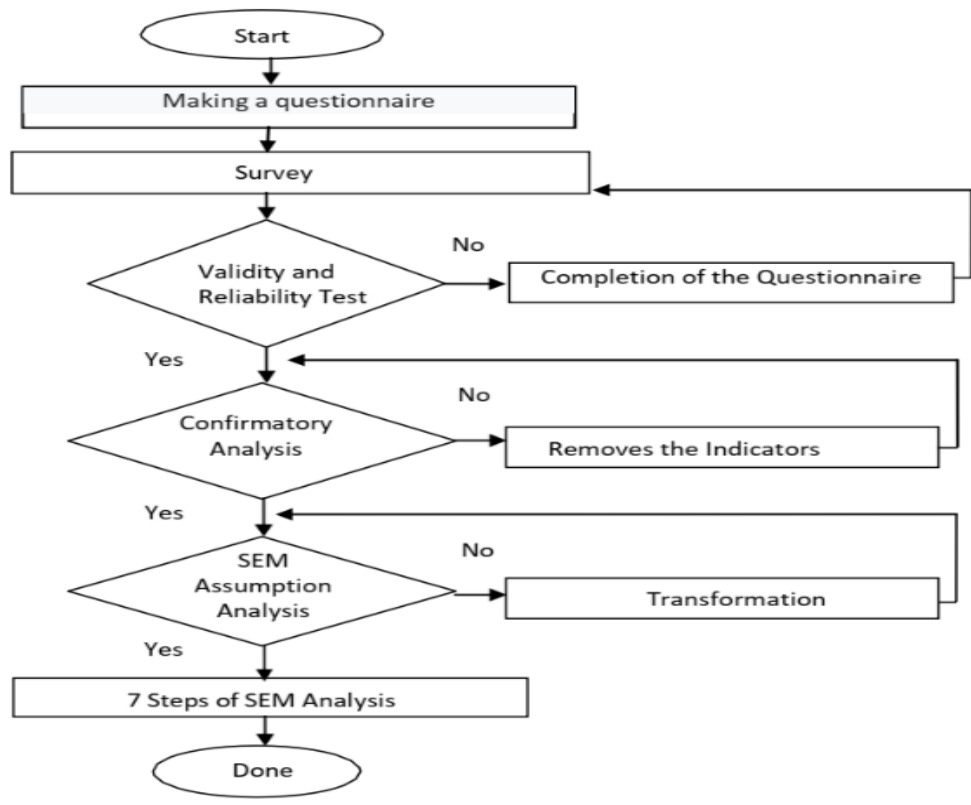

Figure 2. Research Flowchart

\section{Results}

The results of the full model analysis of this study are presented in the following figure:

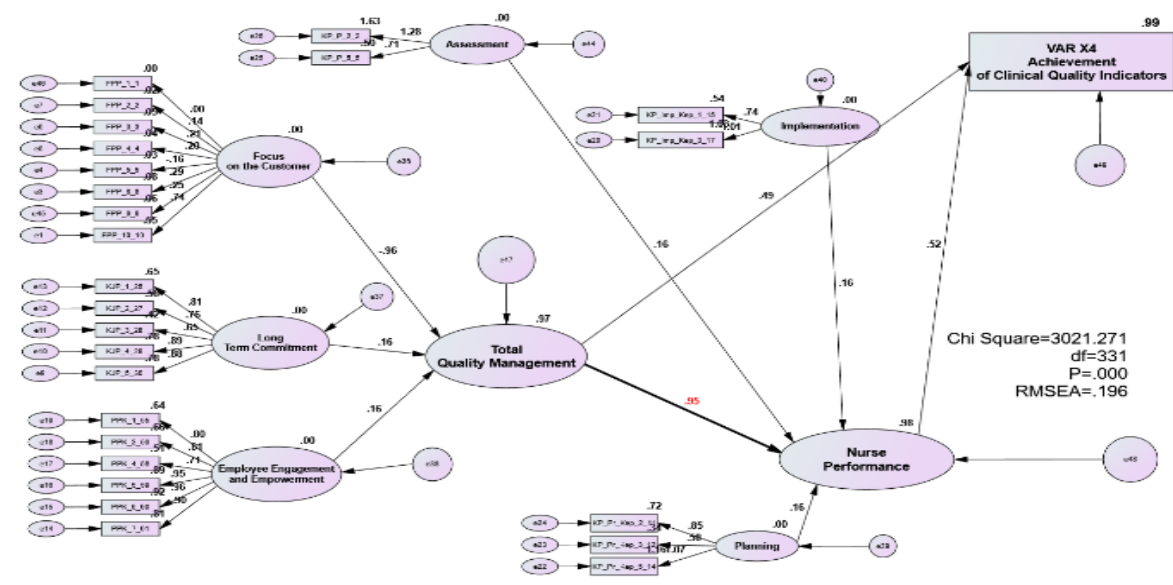

Figure 3. Full Model Analysis 
Hypothesis testing is conducted to determine whether the independent variable affects the dependent variable or not. Testing of the proposed hypothesis can be seen from the results of the significance value of the Regression Weight $(\lambda)$ and the following results are obtained:

Table 2. Hypothesis Test

\begin{tabular}{|l|l|l|c|c|c|c|c|c|}
\hline & & Estimate & S.E. & C.R. & P & $\begin{array}{l}\text { Standardized } \\
\text { Regression } \\
\text { Weights ( } \lambda\end{array}$ & Hypothesis \\
\hline TQM & $\rightarrow$ & $\begin{array}{l}\text { Outcome } \\
\text { Clinical } \\
\text { Quality } \\
\text { Indicators }\end{array}$ & 1,000 & - & - & - & 0,492 & $\begin{array}{c}\mathrm{H} 2 \\
\text { Accepted }\end{array}$ \\
\hline $\begin{array}{l}\text { Nurse } \\
\text { Performance }\end{array}$ & $\rightarrow \begin{array}{l}\text { Outcome } \\
\text { Clinical } \\
\text { Quality } \\
\text { Indicators }\end{array}$ & 1,000 & - & - & - & 0,517 & $\begin{array}{c}\mathrm{H} 3 \\
\text { Accepted }\end{array}$ \\
\hline TQM & $\rightarrow \begin{array}{l}\text { Nurse } \\
\text { Performance }\end{array}$ & 1,000 & - & - & - & 0,949 & $\begin{array}{c}\mathrm{H} 4 \\
\text { Accepted }\end{array}$ \\
\hline
\end{tabular}

Hypothesis 2 in this study is that TQM has a positive effect on the achievement of clinical quality indicators, the test results show that the effect is $49 \% . \mathrm{H} 0$ is rejected and $\mathrm{H} 1$ is accepted, which means that in this study TQM has a positive effect on the achievement of clinical quality indicators.

Hypothesis 3 in this study is that the performance of nurses has a positive effect on the achievement of clinical quality indicators, the test results show that the effect is $51 \%$. It can be concluded that $\mathrm{H} 0$ is rejected and $\mathrm{H} 1$ is accepted, which means that the nurse's performance has a positive effect on the achievement of clinical quality indicators.

Hypothesis 4 in this study is that TQM has a positive effect on nurse performance.Based on the data processing presented in the table above, it is known that the regression coefficient value is 0.949 or $94 \%$, it can be concluded that $\mathrm{H} 0$ is rejected and $\mathrm{H} 1$ is accepted, meaning that in this study TQM has a positive effect on nurse performance.

Simultaneous test was conducted to determine the simultaneous effect of endogenous variables on exogenous variables. In this study, to determine the effect of TQM on the variable performance indicators of clinical quality mediated by the performance of nurses. Hypothesis 1 in this study is that TQM has a positive effect on the achievement of clinical quality indicators mediated by the performance of nurses.

Table 3. Standardized Total Direct, Indirect Effects

\begin{tabular}{|l|c|c|}
\hline & TQM & Nurse Performance \\
\hline Nurse Performance & 0,949 & - \\
\hline $\begin{array}{l}\text { Outcome Clinical } \\
\text { Quality Indicators }\end{array}$ & 0,983 & - \\
\hline
\end{tabular}

Based on the results of data processing presented in table 3, it is known that the regression coefficient value is 0.983 . This influence is very large and almost perfect, so it can be said that a good TQM program in the inpatient unit of the Tangerang District Hospital will cause the performance of nurses to increase and can produce output in the form of excellent clinical quality indicators and meet the targeted standards, it can be concluded that $\mathrm{H} 0$ rejected and $\mathrm{H} 1$ accepted. 


\section{Discussion}

Hypothesis 1 proposed in this study is that TQM has a positive effect on the achievement of clinical quality indicators mediated by the performance of nurses. This study states that the TQM variable has an indirect positive effect on the achievement of clinical quality indicators mediated by the performance of nurses by $98 \%$.

TQM is a management approach to an organization, centered on quality, based on the participation of all its members and aims for long-term success through customer satisfaction and benefits for all members of the organization and society.

In his book entitled Juran's Quality Handbook, Sixth Edition (2010), Joseph M Juran says that Strategic Quality Management is a three-part process based on staff at different levels who make a unique contribution to quality improvement. Senior managers have a strategic view of the organization, middle managers have an operational view of quality and employees have responsibility for quality control.

This theory supports the results of existing research where it was found that the TQM program had an indirect effect on the achievement of clinical quality indicators which were the output of services provided by the hospital to its customers.

The direct effect of TQM on the performance of nurses will certainly have a positive impact on the quality of performance performed by each nurse in the inpatient unit so that it will produce good and quality services according to existing standards.

Hypothesis 2 proposed in this study is that TQM has a positive effect on the achievement of clinical quality indicators. This study proves that the TQM variable has a positive effect on the achievement of clinical quality indicators, namely by $49 \%$.

Based on these results it is known that TQM is very important to run in a hospital that prioritizes service quality, from the 10 dimensions of TQM, management must prioritize 3 main dimensions, namely focus on customers, long-term commitment and employee involvement in every activity. which is executed.

This research is also in line with previous research which states that there is a positive effect of process quality management on product quality performance in manufacturing companies in Indonesia (Yanuar Ramadhan, 2015).

Hypothesis 3 in this study is that there is a positive influence on the performance of nurses on the achievement of clinical quality indicators. From the analysis, it was found that the nurse's performance had a positive effect of $51 \%$ on the achievement of clinical quality indicators. Based on these results, it can be said that the better the performance of the nurses, the better the clinical quality indicators are.

In addition, the results of this study are in accordance with the theory which says thatthe definition of performance refers to the level of success in carrying out tasks and the ability to achieve predetermined goals. Performance is declared good and successful if the desired goals can be achieved well (Donelly, Gibson, \& Ivancevich, 2012).

Hypothesis 4 proposed in this study is that there is a positive effect of TQM on nurse performance. The results of this study indicate that there is a positive effect of TQM on nurse performance by $94 \%$. Based on these results it can be explained that the better the TQM approach is implemented, the better the nurse's performance.

The effect of TQM is $94 \%$ on nurse performance because TQM is a quality-based system approach and involves all individuals in the organization including nurses so that it will affect the performance carried out.

\section{Conclusion}

The TQM variable has a greater direct influence on the performance of nurses than the direct effect on the achievement of clinical quality indicators, while the achievement of 
clinical quality indicators is mostly influenced by the performance of nurses, which is $51 \%$. The TQM variable simultaneously together with the nurse's performance has a very big influence on the achievement of the clinical quality indicator, which is equal to $98 \%$.

Based on data analysis and discussion of research results, it can be concluded as follows: (1) The TQM variable is indirectly mediated by the performance of nurses and has a positive effect on the achievement of clinical quality indicators. (2) TQM has a positive effect on the achievement of clinical quality indicators, meaning that the better the TQM is carried out, the better the achievement of clinical quality indicators is obtained. (3) The performance of nurses has a positive effect on the achievement of clinical quality indicators, meaning that the better the performance of nurses, the better the achievement of clinical quality indicators is achieved. (4) TQM has a positive effect on nurse performance. This means that the better the TQM that is carried out in a hospital, especially in an inpatient unit, the better the performance of the nurses in that unit.

\section{BIBLIOGRAPHY}

Armstrong, A. B. and M. (2007). Human Capital Management Achieving Added Value Through People. Kogan Page Limited.

Aung, K. T., Qurratul, N., \& Binti, A. 2017.Nurses Managers Perspective On Nurses. Enfermería Clínica, 27, 139-143.

Collopy, B. T. (2000). Clinical Indicators in Accreditation: an effective stimulus to improve patient care. International Journal for Qulity in Health Care 2000; Vol 12, Number 3, 12.

David L, Goetsch, S. D. (2010). Quality Management for Organizational Excellence: Introduction to Total Quality (6th, illustr ed.). Prentice Hall, 2010.

Deming, W. E. (1986). Out of the Crisis. Massachusetts.

Gibson, James L., Donnelly Jr, James H., Ivancevich, John M., Konopaske, Robert (2012). Organizationa Behavior, Structure, Processes, Fourteenth Edition (International Edition).1221 Avenue of The Americas, New York, NY 10020: McGraw-Hill.

Goldstein, L. N., Morrow, L. M., Sallie, T. A., Gathoo, K., Alli, K., Mothopeng, T. M. M., \& Samodien, F. (2017). The accuracy of nurse performance of the triage process in a tertiary hospital emergency department in Gauteng province, South Africa. South African Medical Journal, 107(3), 243-247.

https://doi.org/10.7196/SAMJ.2017.v107i3.1111

H. Syarhan, dr., M. (2017). Aplikasi TQM Pada Pelayanan Kesehatan CJH Kab. Tasikmalaya.

Peningkatan Mutu dan keselamatan Pasien RSU Kabupaten Tangerang, (2019). Laporan Capaian Indikator Mutu 2019.

John M. Ivancevich, Michael T. Matteson, R. K. (2017). Organizational Behavior and Management (11th ed.). McGraw-Hill Education, 2017.

Juran, J. (2010). Juran's Quality Handbook: The Complete Guide to Performance Excellence 6/e (Sixth Edit).

Manurung, J. M. (2017). Kajian Implementasi Mutu dengan Pendekatan Integrasi Six Sigma dan TQM Melalui Penilaian Malcolm Baldridge di Rumah Sakit Charitas. Jurnal Administrasi Rumah Sakit Indonesia, 3(2), 127-138.

Patricia A. Potter, A. G. P. (2013). Fundamentals Of Nursing (Eighth Edi). Elsevier Mosby.

Ramadhan, Y. (2015). The Effects of Process Quality Management and Information Technology to Product Quality Performance with Management Accounting System as Intervening ( A Case Study of Manufacture Companies Listed on Indonesia Stock Exchange ). 6(6), 161-173. 
Robert Kreitner, A. K. (2012). Organizational Behavior (10th Editi). McGraw-Hill/Irwin; 10 edition (March 30, 2012).

Santoso, Si. (2015). Menguasai Statistik Parametrik. PT Elex Media Komputindo.

Zeithaml, Valarie A, A. Parasuraman, L. L. B. (2010). Delivering Quality Service. Free Press, 2010 . 